\title{
Can Community Based Tourism (CBT) support Sustainable Tourism in the Osing Traditional Village?
}

\author{
Nur Anita Yunikawati ${ }^{1, *}$, Ni'matul Istiqomah ${ }^{1}$, Magistyo Purboyo Priambodo ${ }^{1}$, Fatimah \\ Sidi $^{2}$ \\ ${ }^{\mathbf{1}}$ Faculty of Economic, Universitas Negeri Malang, Indonesia \\ ${ }^{2}$ Faculty of Computer Science, Universiti Putra Malaysia, Malaysia
}

\begin{abstract}
The tourism sector is one of the effective methods for reducing poverty and inequality for communities in the world. The Community Based Tourism (CBT) is a concept of participation of a community in an area to support tourism activity. The development of a tourist village using the concept of sustainable development should be developed in the Osing Tourism Village. The purpose of this study is to analyze the implementation of CBT carried out by all related parties, namely the Kemiren Village government, the private sector and the village community in supporting Sustainable tourism. This research is a descriptive analytical study with qualitative method approach to obtain propose objective. The research held in Kemiren Village, Glagah District, Banyuwangi Regency, East Java Province. Kemiren Village represents the criteria for research, which is one of the Tourism Villages so called Osing Traditional Village, have elements of culture, environment and economy. The data collection techniques use indepth interviews, documentation, observation and focus group discussion (FGD). The synergy between the tourism driving community of the Osing Traditional Village, the government, and the community greatly contributes to increasing sustainable tourism which is not only oriented towards the economy but also socio-culture and the environmental continuity.
\end{abstract}

\section{Introduction}

Today the tourism sector has become one of the sectors that supports the economic growth of a country. The tourism sector is an effective method for reducing poverty and inequality in several local economic communities in the world $[1,2,3]$. This is because the tourism sector stimulates the creation of various new livelihoods that have not existed before which usually tends to livelihoods that demand the creativity of a person or group in an area [4] as well as new opportunities to introduce and sell local products [5, 6]. During the last few decades research on Community Based Tourism (CBT) has been extensively studied for its existence CBT provide benefits to increase the local economy. CBT methods have been widely applied in various countries such as Amir et al's research findings that indicate that sustainable tourism development in rural areas will contribute to increasing the resilience of

\footnotetext{
${ }^{*}$ Corresponding author : nur.anita.fe@um.ac.id
} 
local communities in Malaysia [7]. In Botsawana CBT, if implemented properly, it can promote natural resource conservation and can increase community participation in tourism [8]. Apart from that CBT in Africa [9] involvement of local communities and the role of politics in community-based tourism development. Thailand is a country that is aggressively offering eco-based and community-based tourism [10]. Other Asian countries such as India through research from Mathew and Sreejesh [11] emphasizing the sustainability of tourism in India is a shared responsibility, both local communities and policy makers. T Dangi and T Jamal explained that the dimensions in the development of CBT must be reviewed and identified in order to know which dimensions still require special attention from all parties [12]. Traditional communities such as rural communities in Taiwan [13], fishing community [14], small island community [15], and communities in Australia [16], implementing CBT development has been proven to have improved the socio-economy of the community.

The application of the CBT concept in Indonesia by involving community participation in an area to support the existence of tourism, one of which is the Tourism Village community. Tourist villages have developed rapidly in Indonesia by presenting local attractions in the form of natural wealth and cultural diversity. The CBT is a concept for the use of a community in an area to support the existence of tourism in an area. The existence of a tourist village has had a significant impact on the local community both from an economic and non-economic side. Application CBT has been widely used in Indonesia, one of which is the application CBT in the area of the Yogjakarta Purba Volcano site [17] that the increase in the quality of the tourist attraction at Mount Purba Nglanggeran has an effect on the satisfaction of tourists visiting Mount Purba Nglanggeran. Tourist satisfaction will have an impact on the loyalty of tourists to revisit Mount Purba Nganggeran. Based on this research, the role of stakeholders and communities, both the general public and the private sector, is to support local tourism. Another study entitled CBT by Rizkianto explains that the management of tourist attractions in Bangun Tourism Village arises from the initiative of the local community, the community agrees to form a tourism village institution, and makes priority programs as the main attraction and the emergence of community business activities as a result of attraction management travel.

Seeing some of the advantages of applying the CBT to form a tourist village, the development of tourist villages in Indonesia is increasingly rapid. Based on BPS data in 2018, the number of tourist villages in Indonesia was 1,734 Tourism Villages, this number is spread across various provinces in Indonesia. East Java Province is one of the provinces that has consistently developed Tourism Villages in all areas of the province of East Java. In 2018 the number of tourist villages in East Java was 54 Tourism Villages. Through the East Java Tourism Office, the East Java Province Tourism Village Association (ASIDEWI) has formed to accommodate and serve as a forum for empowering all tourism village managers in East Java. Banyuwangi Regency is one of the regencies in East Java that is actively increasing the tourism sector, one of which is the Osing Traditional Village. It sells tourist attractions in the form of nature and culture. Based on preliminary observations in the field, it was found that there was an increase in the per capita income of the Osing Village people.

Apart from the advantages of CBT, another side that is lacking in the emergence of a new Tourism Village is the exploitation of natural resources that does not support sustainable development. Sustainable development is characterized by utilizing existing resources by paying attention to social and environmental aspects for the sustainability of these resources. The development of a tourist village using the concept of sustainable development should be developed in the Osing Traditional Village. This article aims to analyze village-based tourism development activities in the Osing Traditional Village located in Kemiren Village, Glagah District, Banyuwangi Regency, East Java Province, Indonesia. The consideration for choosing this village was because Kemiren Village had successfully implemented CBT and was proven to be able to create sustainable tourism. This can be seen in the ability of the main 
actors of Traditional Village tourism in an effort to empower the community so that it has an impact on the economy of local residents. Apart from the economic aspect, the cultural and environmental preservation of local community groups is part of our consideration. All assessments have been acknowledged by a credible institution in the field of local tourism and proven by the recognition received by Kemiren Village as the best tourist village in Indonesia in 2019. The main attraction of this village is to uphold and maintain local wisdom and culture and natural beauty typical of the countryside. In addition, this article also analyzes the respective roles of the main actors so that they can guarantee the existence and support of the welfare of the community [18].

\section{Method}

The location of this research is in Kemiren Village, Glagah District, Banyuwangi Regency. In this study, using primary and secondary data, which is meant by primary data, is data obtained directly from original sources of respondents through in-depth interviews and focus group discussions. Meanwhile, secondary data is data obtained from government agency offices such as the Kemiren Village Government Documentation, Central Statistics Agency $(B P S)$, Banyuwangi Regency Tourism Office. To obtain valid and specific data in accordance with the expected and accountable research objectives, this study uses the following data collection techniques: Observations made, namely the researcher observes the conditions and situations in the field related to the title taken by the researcher in the field. Kemiren Village, Glagah District, Banyuwangi Regency. In-depth interview is a method of collecting data by asking directly and criticizing to the end of the answer to the respondent in a critical and comprehensive manner. Focus Group Discussion (FGD) will be held in Kemiren Village, while those who take part in this activity are representatives of the Kemiren Village government, representatives of youth organizations, representatives of homestay owners and residents of Kemiren Village.

Research analysis using qualitative methods by processing the data obtained during the research process. Data processing in this study is divided into four stages, namely data collection, data analysis, data presentation and drawing conclusions. The tool for processing data in this study uses N-Vivo 10. Researchers will also check the validity of the findings with a credibility test which includes extension of observations, increased persistence and triangulation.

\section{Result}

\subsection{Kemiren Village Overview}

Based on the story of the Kemiren village elders, several sources say that during the Mataram riot, a husband and wife named Marjana and Marni escaped to the Macanputih Kingdom. Marjana who was originally a Mataram soldier who fled and fled to Blambangan. Marjana devoted himself, at that time the Macanputih kingdom was ruled by King Tawang Alun who had a white tiger as a pet. It is said that because of its mighty, the white tiger does not want to eat animal meat but human meat. Every day Prabu Tawang Alun sent soldiers to the villages to look for his citizens with physical disabilities to be brought to the palace and used as food for Raja Tawang Alun's pets. The time came when Marjana's wife had the turn to be brought to the palace, because she was considered physically handicapped (small and thin). Hearing the news, Marjana and his wife finally fled north from the Macanputih kingdom. To evacuate or get away in terms of using language is called "Ngili". While on the run he arrived at a dense forest overgrown with Candlenut trees. This is where Marjana babat alas (forest 
clearing) turned the forest into a settlement / village, and it was called Kemiren Village, because of the many candlenut and durian trees.

Kemiren village is located in Glagah sub-district, Banyuwangi district. Kemiren Village itself is only $3 \mathrm{~km}$ from the city center of Banyuwangi. Kemiren village covers 177,052 hectares with a population of approximately three thousand people. The available agricultural land for food crops is still wide so that it can still be developed. The productivity of food crop agricultural commodities has increased every year. The number of livestock population is quite high, the potential for development as a livestock area, especially for large livestock, because animal feed ingredients are available, including for the development of agricultural and livestock processing industries. as well as the typical Banyuwangi food processing industry such as Dodol (assorted candy), Bolu Kuwuk, Banana Molen, Ladrang, Bagiak, Coffee and various other snacks. From the economic sector of the Kemiren Village community, with the existence of the Tourism Village, the village government as well as the villagers innovates into the service and tourism sector, for example by establishing a homestay which is jointly managed by the village government, Pokdarwis (Tourism Awareness Group) and also the community. So with this the existence of the tourism village can create new jobs. Then the economy of the residents began to increase as well because there was a policy to make Kemiren village a traditional Osing village.

In Kemiren, Osing traditional village whose traditional values are still upheld, this makes many tourists come to visit village to witness the rituals carried out by the community. To make it easier to promote the village, Kemiren village has social media in the form of Instagram, which posts about village traditional activities. The condition of the internet in Kemiren village plays an active role in the modernization experienced by the community.

\subsection{Local Community and Institutional Participation}

The participation of local communities is important in developing sustainable tourism. The local community acts as an actor who determines the success of tourism development. The involvement of the local community can be well realized if in the development of the tourist area they are inflated into the whole process of developing a Tourism Village, starting from the planning stages, implementing activities, and utilizing management results. Based on the Tosun typology [19] forms of public participation are divided into three types of participation, namely coercive participation, motivated participation, and spontaneous participation. Based on this typology, the participation of the Osing Traditional Village is included in the type of driven participation.

"The beginning was 20052006 by Mr. Basofi, ehm 1995 - 1996 by Mr. Basofi Sudirman, the governor of East Java, used as a traditional tourism village of Osing which then built a tourist spot, namely the Osing tourist platform" (Mr. Arifin, Head of Kemiren Village)

According of the results of our interview with the Head of Kemiren Village, it was stated that the formation of the Osing Traditional Village in 1996 and was inaugurated by the Governor of East Java, Mr. Basofi Sudirman. The existence of this Osing Traditional Village was actually triggered by the participation of all village communities in the development of cultural tourism. The majority of the people of Kemiren Village have from generation to generation been farmers who depend on their livelihoods from agricultural products, but in line with the development of the Osing Traditional Village, many people have now switched professions to the tourism sector. The participation of the Kmiren Village community in the development of the Osing Traditional Village cannot be separated from the interference of various parties, namely stakeholders, both from elements of the private government, such as the Ministry of Villages, Development of Disadvantaged Areas and Indonesian 
Transmigration, Ministry of Tourism, East Java Government, Banyuwangi Regency Government, Bank Indonesia (BI), and Bank Mandiri. Each stakeholder has a role in supporting the participation of the Kemiren Village community, such as by providing training in human resource development, capital assistance and equipment assistance.

As stated in Law No. 10 of 2009 concerning Tourism, it explains that the tourism business is an effort to provide goods or services to meet the needs of tourists and to organize tourism. To support this, the participation of the Osing Traditional Village community includes providing cultural tour packages, producing products in the form of processed coffee and other culinary delights, as tour guides and managing homestays. Participation by the community is familial in nature so that it does not cause social jealousy.

The tour packages offered by the Kemiren Traditional Village include cultural tourism, educational tours and culinary tours. Under the auspices of the Village-Owned Enterprise (BUMDES), the Kemiren Village Youth offers a cultural tour package for the Osing Tribe, namely learning to dance the Gandrung dance, besides that they offer performances of "Jaran Goyang Dance", and Barong Arak-procession. In the culinary education package they offer Banyuwangi special culinary packages such as oxtail, ketot, lepet, endog fried gedang, kucur and also "jaran goyang coffee" which is the original product of Kemiren Village. In addition, tourists can also witness and practice traditional coffee roasting.

The making of the tour package was based on the initiation of the Village Youth, and also the Traditional Head of Osing Village together with the Kemiren Village government. This is because to preserve local culture and culture is one of the great potentials for the existence of the Osing Traditional Village. Starting from the formation of youth organizations and then the formation of Pokdarwis (Tourism Awareness Group) in 2017. The formation of Pokdarwis in Kemiren Village was based on PERBUP (Mayor Regulation) No.1 2017 concerning Tourism Villages. Institutionally Pokdarwis is under Bumdes (Village-Owned Enterprise), so everything related to tourism management must go through deliberations between Bumdes and Pokdarwis. This is in accordance with the explanation of resource person Kang Edai, who is the Chairperson of the Pokdarwis Kemiren Village below:

"Pokdarwis itself began to exist since there were technical instructions for the formation of pokdarwis from the ministry of tourism, if not 2009, 2012 there are already instructions on how Pokdarwis was formed, what function it is for, and so on. Then from there, maybe in 2012 that Banyuwangi has started to make the first Banyuwangi Festival event, then continues to develop its tourism, and finally in 2017 Banyuwangi launched PERBUP Number 1 of 2017 concerning Tourism Village, in PERBUP it explains what is a tourist village, what is is in the tourist village, who is the manager of the tourist village. In the management section, it is stated that the Tourism Village is managed by Pokdarwis, of which Pokdarwis is under the auspices of Bumdes (Village-Owned Enterprises). Then the formation of Pokdarwis was also attended by the BPD, the Village Head, and there are these members. So the point is for the formation of Pokdarwis itself, there is already a foundation from the government, so we don't just form it, then there is a Pokdarwis organization, no, but there are already instructions on what its formation will look like. The technical guidance from the Ministry of Tourism in 2009, then, is also in PERBUP No.1 of 2017 concerning Tourism Villages in Banyuwangi. Every region has differences" (Kang Edai, a pioneer of the Osing Traditional Village Youth)

Apart from Pokdarwis, there is an association also in Kemiren Village, namely Paguyuban Tulik Kemiren. This Association consisting of senior initiators of the Traditional Village. The existence of this association is as a senior in terms of tourism development besides this association as one that embraces village youth so they want to participate in the development of tourism villages. This association functions as a group that guides 
POKDARWIS in various matters, particularly in developing various festivals which are held regularly every year. One of the famous festivals is the "10,000 coffee" festival. This festival was initiated by Paguyuban Tulik Kemiren, which in fact already has a coffee shop and produces the typical coffee of Kemiren Village, namely Kopi Jaran Goyang. In addition to attracting tours to visit Kemiren Village, the "10,000 coffee" festival is an event for branding Jaran Goyang Coffee products typical of Kemiren Village and also cups that are typical of Kemiren Village, this is as explained by Mr. Matsuki, a resident of Kemiren Village.

\begin{abstract}
"Kopiuluh ewu, although the coffee is not the origin of the original kemiren, the commodity of kemiren is not coffee, but what we want to highlight is that the cup was actually in another village, Miss, so the uniqueness of the kemiren is like that, Ma'am and that is what we really want to raise. ". (Mr. Matsuki, a resident of Kemiren Village)
\end{abstract}

In addition to the excellent roles of the community, both POKDARWIS and Paguyuban Tulik Kemiren, religious leaders and leaders have also played a big role in developing Kemiren Village as an Osing Traditional Village. One of them is the Tumpeng Sewu tradition, this tradition has been carried out from generation to generation. The Tumpeng Sewu tradition is a series of festivals held by the Banyuwangi Regency which is routinely carried out every year by serving around a thousand tumpeng and the tumpeng is served by residents on the street in the front yard of the house to be eaten together. This tradition is held every Dhulhijjah month (Islamic calendar). The philosophy behind this tradition is so that village communities avoid distress. This tradition has been proven to increase the number of tourist visits who want to witness this tradition firsthand. This ritual starts at $06.00 \mathrm{PM}$ or after Maghrib prayer. Everyone present at the event sat on a mat around the tumpeng which was covered with banana leaves. Besides that, the typical tumpeng side dishes of Kemiren Village residents are pecel pitik (chicken dish) and vegetables.

Lodging is one of the supporters of the sustainability of a tourist spot. Kemiren Village to highlight the characteristics of the Osing Customary, a well-organized homestay was formed. This homestay is the home of a native of Kemiren Village which has a characteristic original form of the Osing tribe's traditional house with ancient architecture and household furniture. This is an attraction for tourists to come to Kemiren Village. This homestay was formed by the initiation of Pokdarwis and the village government. A total of approximately Fifty homestays in Kemiren Village are jointly managed.

\begin{abstract}
"Before starting the homestay there is a mutual agreement, and there must be homestay transparency, the money goes to us first, from the manager, when we check out then we will give the money. We have records regarding the use of a homestay, so that if it's a good turn, and if someone protests we have the data. So the booking is through us, from booking.com, Agoda, then we manage, our guests come to take them to the residents' houses "(Krisna, citizens of Kemiren Village)
\end{abstract}

The Village Government, Pokdarwis and the residents who own the homestay have agreed on the pricing and profit sharing between the homestay owners and the village government. In order to avoid social jealousy from Pokdarwis, which fully manages the distribution of guests for the homestay. All money that goes to Pokdarwis through online ordering and the money is not given to the homestay owner until the guest they serve checks out. In addition, the Village Government supports by providing household furniture assistance to be placed in all homestays so that they are uniform.

Local government support to increase the popularity of the existence of other Osing Traditional Villages is by initiating Pasar Minggu (Sunday Market). This market was founded during the reign of $\mathrm{Hj}$ Lilik Yuliati. At the beginning of the opening of this market, the village government and the Glagah sub-district government provided assistance funds to 
market sellers. This is to increase residents' interest in selling at Pasar Minggu. This market is open every Sunday by selling food and drinks typical of Kemiren Village such as pancakes, kucur, cotton candy, jenang, cenil and others snacks. Until now, Pasar Minggu has become one of the attractions for tourists who want to enjoy the typical culinary delights of Kemiren Village. The interesting thing at Pasar Minggu is that they still uphold the traditions of their ancestors. They peddle their wares along a small alley wearing traditional clothes. In addition, tourists can enjoy the tabuh lesung (traditional instrument from wood) played by the women of Kemiren Village.

\subsection{Community Based Tourism for Sustainable Development}

Sustainable Tourism is a new concept echoed around the world. This is to support sustainable development which includes economic, social and environmental elements. To develop community based tourism, it must be supported by various parties, namely from the government, local communities and the private sector. The development of the Osing Traditional Village already reflects good community based tourism. This is evidenced by the good relationship between the government and the public and the private sector. The government has provided support in the form of funds and also training to improve the human resources for driving tourism in Kemiren Village. This training is in the form of English language skills training for guides conducted by the local government. Then the Central Government through the Minister of Tourism in 2015 provided training on homestay management. The Small Medium Enterprise Cooperative Office often provides packaging and promotion training.

On the other hand, the private sector is one of the contributors to the success of the Osing Traditional Village to become one of the icons in Banyuwangi Regency. Apart from the Osing Traditional Village, another economic buffer is the existence of Osing Tourism. Osing tourism is not part of the tour packages offered by the Osing Traditional Village. However, the existence of Osing Tourism can increase tourist visits to the Osing Traditional Village because Osing Tourism is in one location with the Osing Traditional Village. Osing Tourism offers a hotel that is characterized by Osing in the form of a garden and a swimming pool. Osing tourism indirectly has a positive impact on Osing Traditional Village Tourism, because not everyone wants to stay in a homestay, therefore they can stay at the Osing Tourism hotel and still enjoy the performances offered by the Osing Traditional Village. So that the existence of Osing Tourism is not a competitor but instead becomes a partner for the sustainability of the Osing Traditional Village.

Apart from the government and the private sector, the community is an important actor in the development of the Osing Traditional Village. They volunteered through various existing communities, including Pokdarwis, youth organizations, cultural-loving associations and others who have worked together well to manage and develop the Osing Traditional Village. Customary leaders or cultural observers encourage youth regeneration to learn about the traditions they still hold so far. This is done by making gamelan extracurricular activities, gandrung dances and so on in an elementary school environment. In addition, cultural observers encourage preserving traditional clothes and wearing them when guests visit. Then a good synergy is made between cultural observers and Pokdarwis in managing homestays and culinary tours. They emphasize that homestay and culinary must be identical with the original Osing culture. This was done because what the Osing Traditional Village wanted to highlight was a cultural village.

CBT that goes well will encourage sustainable tourism. This can be seen from the results of our research in the Osing Traditional Village, we found a balance between economy, social, culture, technology and the environment. From the economic aspect, the existence of the Osing Traditional Village through community based tourism has been able to improve 
the economy of the people of Kemiren Village. This is marked by expanding the shift in livelihoods from farmers to tourism. So that it absorbs a lot of labor in the tourism sector. In addition, the empowerment carried out by the village government and Pokdarwis to the community can stimulate the growth of the creative economy in Kemiren Village.

In the social dimension, it is marked by people who are increasingly aware of tourism which contains local wisdom values. Therefore, their insight and mindset are getting more advanced and open because they often interact with tourists. In addition, the village government and Pokdarwis provide a fair division of roles starting from children, adolescents, adults, parents, both men and women who have their respective roles in the development of the Osing Traditional Village. For example, children and adolescents are members of an arts and culture studio, youth organizations and Pokdarwis as initiators and main actors of tourism village development, while womens are in charge of culinary and homestay fields.

Furthermore, the cultural dimension of the existence of the Osing Traditional Village encourages the preservation of the culture and traditions of the Osing Traditional Village community. On the other hand, the increasing number of tourists visiting Kemiren Village, there is a process of cultural exchange between tourists and the community as a learning process in tourism. In addition, the interaction between tourists and the people of Kemiren Village can increase tolerance for cultural differences between tourists and local communities.

In the field of technology, it plays a role in increasing tourists visiting Kemiren Village both from Indonesia and abroad. Pokdarwis has carried out promotions through social media in the form of Instagram, Facebook, TikTok, YouTube and website. The use of this technology is very effective in increasing the number of visits. Because many visitors get information about the existence of Kemiren Village from social media.

In terms of the environment, the increasing number of tourists visiting Kemiren Village, the facilities in the form of village infrastructure are getting better and more complete, because every year there is a special budget for the procurement of facilities. However, garbage is a problems for every tourist actor. Even though trash bins have been provided in various tourist locations, there are still residents and visitors who litter. The village government through Bumdes has created a waste bank in order to reduce the bad habits of Kemiren Village residents in disposing of garbage.

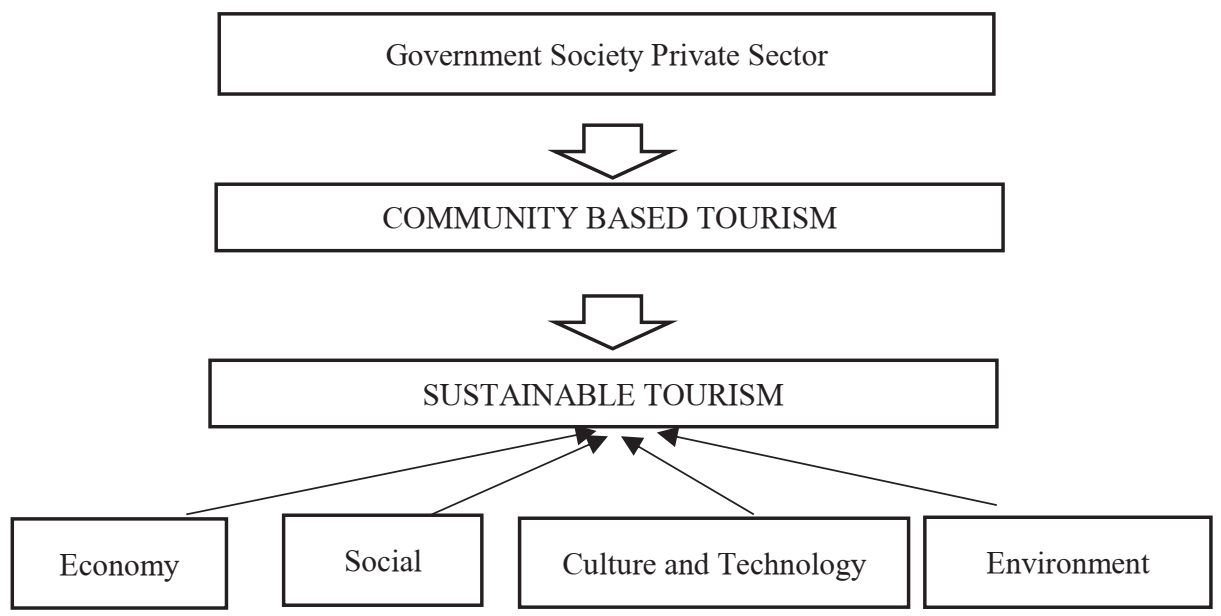

Fig.1. Relationship of CBT to Sustainable Tourism 
The relationship between the dimensions of the development of the Osing Traditional Village CBT cannot be separated because it is connected and supports each another. The application of development principles in the economic, social, cultural, environmental and technological dimensions in their application affects the success of developing CBT for the Osing Traditional Village as shown in the figure below.

\section{Conclusion}

Community Based Tourism (CBT) The Osing Traditional Village in general has fulfilled the principles of developing CBT which is supported by the government, community and private sector. The government as a policy maker has provided regulations that support the sustainability of CBT in Osing Traditional Village. In addition to making regulations on the existence of the government, the government has provided many training to improve human resources and also provide capital assistance to support facilities in the Osing Traditional Village. Local communities with various supports from the government are automatically aware of increasing their capacity in the tourism sector, both in practice and in the field of technology and information development. The private sector has also been influential in collaborating to promote local traditions.

In addition, the existence of the community-based Osing Traditional Village has encouraged sustainable tourism. Directly the Osing Traditional Village has increased the income of the Kemiren Village community through new family-based livelihoods. In addition, the emergence of a creative industry for souvenirs typical of Kemiren Village has reduced the seasonal unemployment of residents. The social sector has been shown to increase unity among residents to manage joint tourism. So that the culture that is the tradition of the ancestors does not become extinct and actually becomes an attraction. The rapid development of technology also encourages tourism industry players to use technology to market the Osing Traditional Village tourism. This has proven to increase the number of visits to this village. Finally, the environment in Osing Village is still beautiful and this beauty is a weapon for this village that can be sold to tourists. However, more and more tourists visit the Osing Traditional Village.

\section{References}

1. C. Qian, N. Sasaki, D. Jourdain, S. M. Kim, and P. G. Shivakoti, "Local livelihood under different governances of tourism development in China - A case study of Huangshan mountain area," Tour. Manag., 2017, doi: 10.1016/j.tourman.2017.01.006.

2. A. Giampiccoli and M. Saayman, "Community-based tourism, responsible tourism, and infrastructure development and poverty," African J. Hosp. Tour. Leis., 2017.

3. M. Saayman and A. Giampiccoli, "Community-based and pro-poor tourism: Initial assessment of their relation to community development," European Journal of Tourism Research. 2016.

4. "World Ecotourism Summit 2002," J. Ecotourism, 2002, doi: 10.1080/14724040208668128.

5. T. H. Lee, "Influence analysis of community resident support for sustainable tourism development," Tour. Manag., 2013, doi: 10.1016/j.tourman.2012.03.007.

6. T. H. Lee and F. H. Jan, "Can community-based tourism contribute to sustainable development? Evidence from residents' perceptions of the sustainability," Tour. Manag., vol. 70, no. September 2018, pp. 368-380, 2019, doi: 
10.1016/j.tourman.2018.09.003.

7. A. F. Amir, A. A. Ghapar, S. A. Jamal, and K. N. Ahmad, "Sustainable Tourism Development: A Study on Community Resilience for Rural Tourism in Malaysia," Procedia - Soc. Behav. Sci., 2015, doi: 10.1016/j.sbspro.2014.10.217.

8. L. S. Sebele, "Community-based tourism ventures, benefits and challenges: Khama Rhino Sanctuary Trust, Central District, Botswana," Tour. Manag., 2010, doi: 10.1016/j.tourman.2009.01.005.

9. M. Mayaka, W. G. Croy, and J. W. Cox, "Participation as motif in community-based tourism: a practice perspective," J. Sustain. Tour., 2018, doi: 10.1080/09669582.2017.1359278.

10. P. Wiltshier, A. Clarke, A. Adebayo, P. Robinson, and A. Oriade, "Community-based tourism," in Community-Based Tourism in the Developing World, 2019.

11. P. V. Mathew and S. Sreejesh, "Impact of responsible tourism on destination sustainability and quality of life of community in tourism destinations," J. Hosp. Tour. Manag., 2017, doi: 10.1016/j.jhtm.2016.10.001.

12. T. B. Dangi and T. Jamal, "An integrated approach to "sustainable community-based tourism," Sustain., 2016, doi: 10.3390/su8050475.

13. C. C. Wang, C. Cater, and T. Low, "Political challenges in community-based ecotourism," J. Sustain. Tour., vol. 24, no. 11, pp. 1555-1568, 2016, doi: 10.1080/09669582.2015.1125908.

14. C. Thompson, T. Johnson, and S. Hanes, "Vulnerability of fishing communities undergoing gentrification,” J. Rural Stud., 2016, doi: 10.1016/j.jrurstud.2016.03.008.

15. L. S. L. Teh, D. Zeller, A. Cabanban, L. C. L. Teh, and U. R. Sumaila, "Seasonality and historic trends in the reef fisheries of Pulau Banggi, Sabah, Malaysia," Coral Reefs, 2007, doi: 10.1007/s00338-006-0182-x.

16. H. Della Bosca and J. Gillespie, "The coal story: Generational coal mining communities and strategies of energy transition in Australia," Energy Policy, 2018, doi: 10.1016/j.enpol.2018.04.032.

17. H. Hermawan, "PENGARUH DAYA TARIK WISATA, KESELAMATAN, DAN SARANA WISATA TERHADAP KEPUASAN SERTA DAMPAKNYA TERHADAP LOYALITAS WISATAWAN : Studi Community Based Tourism di Gunung Api Purba Nglanggeran," Wahana Inf. Pariwisata MEDIA WISATA, vol. 15, no. 1, 2017, doi: 10.31219/osf.io/89hqd.

18. P. Mason, Tourism impacts, planning and management. 2012.

19. C. Tosun, "Towards a typology of community participation in the tourism development process,” Anatolia, 1999, doi: 10.1080/13032917.1999.9686975. 